\title{
How Should Citizens' Collective Liability for State Action be Grounded?
}

\author{
Robert Huseby \\ roberthu@stv.uio.no \\ University of Oslo, \\ Department of Political Science \\ P. O. Box 1097 Blindern \\ 0317 Oslo, Norway
}

\begin{abstract}
:
This paper assesses one type of justification for collective liability - the democratic authorization account - according to which citizens can be held liable for what their state does, because they collectively authorize the state's actions. I argue that the democratic authorization view, properly understood, has an implausibly narrow scope, which risks leaving many victims of injustice without compensation. Hence, I propose a subsidiary account which is wider in scope, and which applies to most cases of state-inflicted harm. This view picks out liable agents on the basis of a) their ability to bear the compensatory burdens, b) the incentives that the prospect of liability give citizens to hold their states in check, and c) distributive concerns. Lastly, I address the relationship between citizens who are (merely) collectively liable for some harm, and citizens who are to some extent morally responsible (for instance in virtue of having endorsed the state-inflicted harm).
\end{abstract}

\section{Keywords:}

Ability to Compensate; Collective Liability; Democratic Authorization; Fairness; Incentives 


\section{How Should Citizens' Collective Liability for State Action be Grounded?}

Sometimes states act impermissibly, illegally, or unjustly, in such a way that they ought to compensate the victims of their acts (Parrish, 2009; Stilz 2011; Pasternak 2011). ${ }^{1}$ Examples include the unjust waging of war, discriminatory or racist domestic policies, heavy pollution causing damages overseas, or the contribution to severe poverty, at home or abroad. If imposed, the actual burdens of such compensation will ultimately fall on citizens (Stiltz 2011, 190; Pasternak 2011, 188). Several authors have argued that such seeping-down of collective liability to compensate the victims of state action is morally justifiable (Rawls 1999; Miller 2007; Parrish 2009; Pasternak 2011; Pogge, 2002; Stilz 2011; 2010, Nagel 2005). Some of these authors further suggest that the case for collective liability is especially strong in democratic states, since democratic citizens have at least some say over what policies the state pursues. None of them, however, deny that members of nondemocratic states may sometimes also be held liable for damages inflicted by their governments.

Liability, collective or not, is distinct from both moral and causal responsibility (See Pasternak 2011, 189). When a state commits an illegal or unjust act, some state leaders, government officials, generals, or soldiers may of course be morally responsible in various ways and to varying degrees. This is sometimes true of individual citizens too, but the main question here is whether even those citizens who are not morally responsible can nevertheless be liable for what their state does. ${ }^{2}$ Liability concerns who we should pick out as the right bearers of the burden to compensate for some inflicted (wrongful) harm. ${ }^{3}$ This is important, because sometimes the morally responsible agent is unable or unwilling to assume his or her 
duties. In such situations, other agents may be singled out, with reference to some morally salient fact about them.

The purpose of this paper is to assess one type of justification for collective liability the democratic authorization account, recently defended by Anna Stilz (2011), John Parrish (2009), and, in passing, Thomas Nagel $(2005) .{ }^{4}$ On this view, citizens can be held liable for what their state does, because they collectively authorize the state's actions. The liable agents, the citizens, are not necessarily seen as morally responsible for the harm. But since they authorize the agent that inflicts the harm, they should be held liable. The state acts for them, on their behalf, and the costs and benefits associated with these acts attaches to them, rather than anyone else. ${ }^{5}$

In my view, it is crucial that theories of collective liability have a wide scope. A central motivation behind such accounts is the fear that the innocent victims of state-inflicted harms such as unjust wars and racist policies, may end up without compensation. Both Parrish $(2009,124)$ and Stilz $(2011,196)$ explicitly share this worry. ${ }^{6}$ I will argue that the democratic authorization view fails to adequately meet this challenge. Hence, I will propose an expanded account which is wider in scope, and which will apply to most cases of state-inflicted harm. This view picks out liable agents based on a) their ability to bear the compensatory burdens, b) the incentives that the prospect of liability might give citizens to hold their states in check, and c) distributive concerns. This account does not contradict the democratic authorization theory. Rather, it is compatible with it, and may serve as a subsidiary principle that takes effect when the democratic authorization account fails. ${ }^{7}$

In the next section, I present Stilz' and Parrish's respective versions of the democratic authorization view. ${ }^{8}$ The two subsequent sections critically assess their accounts, particularly with regards to (external and internal) scope. In the fifth section, I present my subsidiary account of how citizens can be held collectively liable for their state's acts. In the penultimate 
section I address the relationship between citizens who are (merely) collectively liable for some harm, and citizens who are in addition, to some extent morally responsible (for instance in virtue of having endorsed the state-inflicted harm). The last section concludes.

\section{Democratic Authorization}

Stilz claims that citizens are liable for state action to the extent that they are obligated to obey the laws of the state, and that they are politically obligated to the extent that the state is democratically authorized $(2011,198)$. A state is democratically authorized by its citizens, if they have sufficiently good reason to affirm their membership in the state. This will be the case if their will is appropriately implicated in the state's acts. For this criterion to be met, the citizens must have specific moral (as opposed to merely prudential) reasons to obey the law and support the institutions of the state $(2011,198)$. These moral reasons arise from realizing “...that a condition in which we are entitled to judge and execute our own rights is very unfavorable to securing them $(2011,200)$." Therefore, we ought to “...accept an arbitrator's judgments, since we gain by having reference to a unitary public interpretation of our rights, as coordination is a necessary condition for freedom from interference by other people (2011, 200).”

In other words, if we were all, individually, to interpret, claim, and defend our own rights, chaos would most likely ensue. Our rights are more effectively secured if we agree to let the state to protect them, even if doing so, in some cases, might imply that we have to accept judgments and decisions that we disagree with and think are wrong. This is analogous to sports teams' need for a referee. Even if both teams accept the offside rules, they need a referee to decide whether a player is offside or not in particular cases. This is true even if the teams often disagree with the referee, and even if the referee sometimes gets it wrong. The alternative is still clearly worse. 
There are some limits however. On Stilz' view a state is authorized when its laws qualify as a possible general will, by passing a minimal threshold for taking each citizen's interests into account $(2011,200)$. A legitimate constitution must secure "the freedom of each member of society as a human being, his equality with all others as a subject, and his independence as a citizen $(2011,202) .{ }^{\circ 9}$ When this minimal threshold is passed, citizens should do as the state commands, because they then better secure their rights than if they rely on their own judgment $(2011,200){ }^{10}$ "If the constitution meets these criteria, the state is authorized with respect to me, even if I disagree with its acts $(2011,200)$." When this is the case, moreover, citizens may be held collectively liable for the state's acts and policies.

Parrish grounds his account in Klosko's theory of state authority, which is based on “...our shared need for the state as a background condition for living acceptably commodious lives.” This includes “...collective self-defence, law enforcement, economic coordination, and basic social services... $(2009,130)$ " The state is the only institution capable of securing these conditions, and citizens who need them (that is, most of us) “...may be seen from a normative point of view, as authorizing the existence of the state that alone makes that project feasible (2009, 131).”

When the citizens thus authorize the state, a principal-agent relationship is established. ${ }^{11}$ This relationship "...commits us to prima facie obligations to take responsibility for the consequences of [the state's] actions (Parrish 2009, 132)."12 This goes not only for the existence of the state as such, but also for the "... consequences of the form of [the] state", at least to some extent $(2009,132)$. Among the potentially relevant aspects of states are centralized governments with military powers and capabilities. If this is necessary to fulfill the citizens' needs for, say, security, this implies that the state may also involve its citizens in military conflict $(2009,132)$. Authorization, moreover, is granted as a general power, rather than licensed on a case-to-case basis (Parrish 2009, 133. See also Stilz 2011, 
200). This could further result in liability for just or unjust warfare on the part of the citizens, even for those who were opposed to the war, though their liability is less extensive than that of those who supported it (Parrish 2009, 149). It does not hold, however, for citizens of other states who endorsed similar policies, if their state did not implement it. For citizens to free themselves completely from liability, irrevocable disassociation from the state is necessary (Parrish 2009, 150. See also Pasternak 2013).

On both these views, then, citizens can be bound by, and liable for, the state's acts even if these acts are wrong, to the extent that the acts count as a credible interpretation of the citizens' rights, or to the extent that the state secures necessary background conditions. This means that the state must be above some threshold of legitimacy.

\section{The External Scope of Democratic Authorization}

Stilz and Parrish both illustrate the implications of their theories with reference to the 2003 war against Iraq. They argue that US (and UK) citizens are liable to pay a share of the compensation owed to Iraqi citizens, because the war was illegal, unjust, or both (Stilz 2011, 205; Parrish 2009, 148). ${ }^{13}$ This raises the question of the extent to which citizens can be held liable for the wrongful acts of their state. Where should the line be drawn?

According to Stilz, obligation and liability extends even to cases of power abuse on the part of the state $(2011,206)$. Parrish's view is quite similar. He holds that the state is prima facie entitled to "... act as our agent in a morally real sense in all but the most extreme and obviously bogus claims of authorization (2009, 148-9)." It seems then, that both Stilz and Parrish hold that some level of insincerity (on the part of the state) is compatible with authorization. In my view, this feature is interesting with regards to the authors' understandable wish to avoid cases of responsibility shortfall. The reason is that citizens are not to be held liable for unjust and illegal wars in cases where the aggressor state's 
government is too insincere, dishonest or manipulative. Whenever wars are instigated under (sufficiently) false pretense, the government is not credibly interpreting the rights of their citizens on Stilz' view, and its claim to authorization would also be obviously bogus in Parrish's sense. Thus, there might be many cases in which citizens are not liable, and the victims must go uncompensated.

Nevertheless, the democratic authorization account appears to be even more restricted than its proponents realize. Parrish, as noted, sees the relation between the state and its citizens as a principal-agent relationship. Stilz is on to a similar idea in her discussion of an analogy involving a guardian acting on behalf of a ward $(2011,201)$. The idea is that the state's acts are our acts, by proxy, as it were. Clearly, one can be liable for what one's agent does in one's name. But there are limits to this. As Stilz suggests, we are liable to the extent that the agent keeps within her mandate $(2011,201)$. If I let an investor take care of my money, I let her decide what stocks to buy and sell. If things go well, I keep the gains, and if not, I accept the losses. However, if the agent-investor goes outside her mandate, and engages in insider trading or gambling, say, I am not liable (for either gains or losses), at least not simply in virtue of being a principal (see Stilz 2011, 201).

Given Parrish's and Stilz' assessments of the war against Iraq, and given that both refer to principal-agent relationships to illustrate the democratic authorization account, it is fair to ask why, in this case, the principal has to accept liability for the agents' acts even when they are unjust or illegal? If the state is our agent, we should accept liability for what it does, as principals, only to the extent that it acts within its mandate (as Stilz holds, and as seems reasonable). While it is unclear exactly what this mandate entails, established international law and the core principles of the just war tradition surely make out some of the relevant constraints. $^{14}$ 
Consider the alternative: a principal is liable for the agent's acts even if these acts are illegal or unjust. That does not sound right, at least not as a general rule. The reason is first that this would make principal-agent relationships very risky for the principal, thus undermining the social usefulness of such relationships, and secondly that it would sometimes be morally problematic to let innocent and well-intentioned principals pay the price for the reckless, devious, or malicious acts of agents. Note that for Parrish and Stilz, liability is the upshot of authorization. Citizens are liable for the actions they authorize the state to perform in their name. If the liability extends to unjust and illegal acts, this implies that citizens, here and now, authorize their governments to act even in ways that are illegal and unjust. Parrish might be right to argue that citizens authorize the state to use force on their behalf "....as a general power, rather $\ldots$ than on a specific, case-by-case basis $(2009,133) . "$ But as indicated, this does not provide an adequate answer to the question of scope, because the quote is quite compatible with a license that is "general within certain limits," that is, within a mandate.

One answer might be found in the way Stilz and Parrish ground authority in the first place. Both hold that we need the state (for securing rights arbitration or background conditions), and so long as the state provides what we need, and we have no alternative ways of getting it, we authorize the state to act on our behalf (Stilz 2011, 202; Parrish 2009, 131). Now, even if authorization might get off the ground through such accounts, it is hard to see what justifies authorization that extends even to illegal and unjust wars. Why should it be the case that even if I prefer having a state to not having a state, or do better by having a state than not, I should accept liability for (almost) anything the state does? Of course, there is the issue of responsibility shortfall, which is clearly important. But on the democratic authorization account, this provides a motivation, not a reason, (though, as I will elaborate below, I think it counts as a reason in its own right).

Suppose there are three alternatives rather than two: 

1) No state
2) Any state (fulfilling the minimal criteria/ securing background conditions), and
3) Decent states (fulfilling the minimal criteria/ securing background conditions).

By decent states, I mean states that sincerely attempt to abide by international law and the main theses of the just war tradition (this definition, of course, is tailored to the leading illustration). If it is relevant that I would prefer 2 to 1 , it should also be relevant that I prefer 3 to 2. If so, this would affect the limits of authorization. More generally, both Parrish and Stilz set up some minimal criteria the state must meet in order to count as authorized, and then suppose that this authorization is quite extensive. Neither provide, as far as I can see, a specific argument to back up the claim that any minimally legitimate state is authorized to conduct illegal or unjust wars. Nor do they provide much justification for the legitimacy thresholds they think states ought to pass. Hence, it is unclear why, on the democratic authorization account, citizens are held collectively liable in cases like the war against Iraq.

Notice that my argument does not hinge on the actual moral or legal status of the war against Iraq. The point is to suggest that Stilz and Parrish stretch the concept of authorization too far. They hold that the war is illegal (and unjust, in Parrish's case), yet they think the citizens have authorized their government to (among other things) wage the war. In my view, if the war was illegal (and unjust) the state has gone beyond its mandate.

To be sure, it will be difficult to define the limits of authorization. One could argue that the legality or morality of many state acts and policies, including the war against Iraq, will be subject to controversy. My gesturing at international law and the principles of just war does not suffice to put this worry to rest. I agree that this is a problem, but this problem will arise on any account that does not imply carte blanche authorization. Both Stilz and Parrish 
shy away from this, and hence both draw some kind of limit, and in both cases the limits are (understandably) vague. I will not be able to solve this problem, but I will still maintain that there is a principled difference between holding citizens liable for (because they are assumed to have authorized) state acts that are unjust or unlawful, and not doing so. Holding citizens liable for such acts, moreover, does not seem justified on the democratic authorization account. These basic points are not, I think, undermined by the inherent difficulty of precisely defining the limits of lawful and morally permissible state action.

Notice that my criticism is directed at the concept of authorization employed by Stilz and Parrish. My aim is to argue that it is implausible to say that the citizens authorize their state, when the state acts outside its mandate. If this is true, the scope of the account is narrower than one might initially think. As will become clear below, I do in fact think that citizens can (and should) be held liable for state acts even in cases where the state acts illegally or unjust. But if so, the reason cannot be that the state is authorized by its citizens. Liability has to be grounded elsewhere.

Note that citizens, as principals, may sometimes actually authorize unjust acts, for instance in a referendum about whether or not to engage in ethnic cleansing. In such cases, it seems fair to say that the citizens (or at least some of them), are liable because they authorized the illegitimate state action. But this is different from saying that citizens authorize all state acts (within some quite wide limits), simply in virtue of being citizens of a minimally legitimate state. To illustrate, recall the case in which I let an investor look after my money. As I argued, I would not be liable, simply in virtue of being a principal, if the investor engaged in insider trading behind my back (given that I have taken the necessary precautions and so on). However, this is of course not to say that I am not liable for such insider trading if I actually instruct (and hence directly authorize) the investor to engage in such criminal activity on my behalf. 


\section{The Internal Scope of Democratic Authorization}

Domestic issues may give rise to a different (though related) problem. In some cases, only a subset of the population has democratic rights, or secure background conditions, while another subset is relegated to an inferior status. One example is the way the U.S. government treated black citizens prior to the Civil Rights Act and the Voting Right Act (Stilz 2011, 204). Before 1964, some U.S. citizens were treated as second-rate, and were denied, among other things, the right to vote. Such discriminatory (or worse) policies are morally impermissible, and it is obvious that those citizens who were discriminated against by the law should not be held liable for this objectionable system. As Stilz argues, these citizens are victims, not authors, of state policy $(2011,205)$. How does the democratic authorization account deal with cases like this? Are the enfranchised citizens liable for the harms suffered by the disenfranchised? The answer is not obvious. Here too, much depends on whether or not the state's act can be said to be authorized by the (enfranchised) citizens.

According to Stilz, a state can indeed be authorized with respect to only some citizens. This view stands in some tension with the minimal criteria for legitimacy, one of which demands that the state must ensure each citizen's equality with all others (2011, 202-3). States that discriminate against some of its citizens surely violate this criterion. A citizen might not have any personal complaints if her rights are secured, and she gains (even if others do not) from having the state as an arbitrator of her rights. But does this citizen have a moral reason to obey the laws of a discriminatory, if not outright racist state? This sounds very implausible.

To be sure, moral reasons, in Stilz' view, derive from hypothetical consent. But if hypothetical consent can be given to any system so long as it respects $m y$ rights, it violates standards of impartiality integral to most hypothetical consent theories. Reasons to consent to discriminatory political systems might be rational and prudential, but they seem wanting from 
a moral point of view, precisely because they are grounded merely in self-regard. Accordingly, citizens of states engaged in blatantly discriminatory practices do not have sufficient moral reason to affirm their membership in the state, nor any moral obligation to obey the laws. ${ }^{15}$ If so, the state is not democratically authorized, citizens are not bound by political obligation, and, finally, they are not liable for the unjust acts of their state.

Parrish does not address this issue explicitly. It seems however that the logic of his account implies a similar ambiguity. On the one hand, if the state secures necessary background conditions for leading decent lives only for a subset of the population, and this subset has democratic rights, the state could be authorized with respect to them. They could, then, incur liability for the actions of the state. On the other hand, questions of legitimacy arise on Parrish's account too. As we have seen above, the state's claim to "act as our agent in a morally real sense" does not extend to "the most extreme and obviously bogus claims of authorization (Parrish 2009, 148-9).” As noted, this statement does not provide a clear-cut criterion, but it seems that discriminatory or racist states' claim to authorization is both extreme and obviously bogus.

In any case, my aim here is not to decide whether or not Stilz' and Parrish's accounts imply that discriminatory or racist states are authorized by their enfranchised citizens. Rather, I want to argue that problems arise in either case. Both authors face a dilemma.

Either a), the enfranchised citizens authorize the state, including the discriminatory or racist laws. This is problematic, as already suggested, because it puts a strain on the notion of legitimacy inherent in the theories. Although Stilz is more explicit on this score, it is clear that liability is connected to legitimacy and authorization. If laws are such that citizens can be said to authorize them, this suggests that the state passes some legitimacy threshold. This is highly dubious in the case of states that deny some of their members democratic rights based on for instance skin color. 
Or b), the enfranchised citizens do not authorize the state (because the state does not secure equality for all, or its claim to act on the citizens' behalf is extreme and bogus). This is more plausible with regards to the enfranchised part of the population, but it is easy to see that it severely limits the scope of the democratic authorization account. This path leads headlong into a severe case of responsibility shortfall. Victims of racist policies must, it seems, go uncompensated, because states responsible for such policies are not sufficiently legitimate to ground authorization and liability on the part of the enfranchised citizens. To be sure, individual political leaders and public officials may still be liable (because they are morally responsible), as are, no doubt, many individual citizens. But this will in many cases not be sufficient for compensating the wrong. A theory of collective liability should avoid both horns of this dilemma (to the extent possible). ${ }^{16}$

\section{Ability, Incentives, and Distribution - A Subsidiary Account of Collective Liability}

If the arguments presented above are correct, the theory of democratic authorization provides more limited grounds for assigning collective liability to the citizens of democratic states than Stilz and Parrish assume. The only way to expand the scope of the account seems to be to overstretch the concepts of authorization or legitimacy. This is problematic for reasons already noted. Whenever we lack the grounds for assigning collective liability, we risk leaving the innocent victims of unjust acts committed by states, to their own fate. This will in turn undermine the incentives citizens ought to have to make sure that their state does not violate legal and normative standards, domestically or internationally.

On what grounds then, if any, should we assign liability for harmful acts committed by states, in order to ensure that victims are compensated even when the state is clearly out of bounds (and hence not authorized)? Recall that liable agents are liable not necessarily in virtue of their moral or causal connection to the harm, but (sometimes) merely in virtue of 
some other moral consideration, over which they may have little or no control, for instance benefiting from harm and injustice, or associative ties (Butt 2009; Collins 2016; Miller 2001). I propose a view based on ability, incentives and distributive concerns. In short, the most able agents should compensate, insofar as this a) does not have negative incentive effects (which will often be the case) and so long as it b), does not have counterintuitive distributive effects (this concerns both the relation between potential compensators and between the victim and potential compensators).

The first aspect is inspired by Simon Caney's rendering of the ability to pay-principle in the context of climate ethics. According to Caney, if the morally and causally responsible agent is unwilling or unable to compensate, those (remaining) agents who are able to compensate, should do so. This may at first sound as a rather weak reason for assigning liability to moral agents. Caney argues, however, that if those who are able to, do not compensate (still assuming that the morally responsible agents are unable or unwilling), the cost must either be borne by those that are unable (the poor), or else must be left where it lies, namely with those who are harmed (Caney 2010, 214). ${ }^{17}$ The latter is, in effect, equivalent to rendering the victims liable (to take on the burden of the harm, if not to compensate). In many cases, this is hugely problematic from a moral point of view. Just how problematic it is, will of course depend to some extent on the resource or welfare level of the harmed. In the cases I have discussed here, however, which concerns disenfranchised citizens and victims of unjust wars, it is likely that those who are harmed are generally quite badly off. This need not always be the case, but to the extent that it is, responsibility shortfall will be an acute problem.

It is less certain, though, that the citizens of the state that committed the harmful act are generally able to compensate. And even if they are, one might ask why they, in particular, should be held liable, rather than some other able, or abler, agents. There is so far nothing to connect citizens of particular states to the liability for compensating particular harms. Citizens 
of states that act illegally or unjustly, to the extent that they are able, are merely a subset of the potentially liable agents. In order to supply such a connection, we must first distinguish between different (absolute and relative) levels of ability that the citizens may have to compensate.

(a) The citizens of the harm-inflicting state are not able to compensate the victims.

(b) The citizens of the harm-inflicting state are able to compensate the victims, but less so than any other agents.

(c) The citizens of the harm-inflicting state are equally able as, or abler than, at least some other agents to compensate the victims.

If the citizens are unable, then clearly they cannot compensate. On the ability-reasoning, they are then not liable. ${ }^{18}$ When citizens are not able, some other agents, perhaps the most able, should be held liable to compensate (at least when the victims are not very well off even after they have suffered the harm in question).

In the last two cases, however, the answer turns on further considerations. As noted by Stilz, if citizens in particular are not held liable, this may create perverse incentives, because citizens are not given reasons (apart from those they already may have) to keep their states in check. To Stilz this is a motivating factor behind the democratic authorization account. In my view, it is a reason that should influence the question of liability in its own right. If holding citizens liable can limit the extent of abuse of power (through citizens' control over their governments), this is a good enough reason to single out the citizens of harmful states, as the primary liable agents, among the larger set of able agents. This means that at least in cases falling under category (c), citizens, rather than non-citizens, should be held liable. The reason is a combination of the fact that the citizens are able to take on the compensatory burden, and 
the assumption that the prospect of being held liable gives citizens incentives to do what they can to make sure that the state does not commit unjust or illegal acts. ${ }^{19}$ Notice, however, that this reasoning is contingent to the extent that states' actions will sometimes be influenced by other factors, such as international pressure. In such cases, those actors who are able to exert such pressure may be liable as well, at least to some extent. It seems reasonable to assume, however, that citizens of democratic states will often be well placed to influence their governments.

What about cases in category b), where the citizens are the least able agents? Here we have to weigh distributive concerns (between potential compensators) against the incentive effects. The answer in specific cases has to depend on how able the citizens are in absolute terms, how much less able than others they are in relative terms, and how much is lost in terms of the incentive effect by exceptions to the rule (of holding able citizens liable). The same is true of intermediate cases where the citizens are not the least able, but less able than some or many other agents. Again, however, if the citizens of the state that committed the harm are not, after careful consideration, liable, the liability shifts to other able, perhaps the ablest, agents.

As indicated, the resource or welfare level of the victims can also play a role. If the victims are better off than the citizens of the harm-inflicting state are, the citizens may not be liable. Further, it could be the case that no other agents are liable either, at least if the victims are very well off. This will be equivalent to letting the victim foot the bill. However, this is not necessarily a problem. Many would agree that the poor should not compensate the rich, even if the rich has fallen victim to harm, so long as a) the rich are still better off than the poor, and so long as b) the poor in question are not morally responsible for the harm.

In sum, we first check whether the citizens of the state that committed the unjust act are able to compensate. If not, we start looking for (the most) able alternative duty-bearers. 
However, if the citizens of the state that committed the unjust act are able (and not the least able) to compensate, we let them foot the bill, to the extent that doing so will have positive incentive effects. If and when the incentive effect is, for whatever reason, weak or nonexistent, liability will not stick with the citizens. Instead, we (again) look for other able dutybearers. ${ }^{20}$ Throughout, we check how badly off the citizens of the victim state is, compared to the potentially liable citizens of the harm-inflicting state.

This account is sensitive to the resource or welfare levels of the parties, and it has a very wide scope. It takes account of all cases of responsibility shortfall, save cases in which no one is able to compensate, and cases in which the victim is very well off (in terms of welfare or resources). I suspect such cases to be relatively rare.

Notice that this account involves accepting a form of moral bad luck. Citizens (or other able agents), as a group, ${ }^{21}$ are (sometimes) held liable for outcomes that they are unable to control, and which, from their point of view, are completely arbitrary and matters of (bad) luck. They are able to foot the bill, and letting them in particular foot it, is (sometimes) justified by the incentive effect, rather than by any deeper connection between them and the harm. As indicated, I think we should accept such instances of moral bad luck, because it would be worse to let the victims go uncompensated. The victims are also victims of moral bad luck, and typically to a greater extent than those who are able to pay (when this is not true, however, the victims might have to take the cost themselves). It makes sense, then, to distribute bad luck in accordance with ability to bear it. Further, it seems that citizens of democratic states have reason to accept this scheme. First because it caters to the needs of the victims (at least when the victims are not very well off), and second because it is designed to minimize the extent of wrongful harms committed by states. ${ }^{22}$

So far, I have mainly discussed the external scope of my proposed account. It will be useful also to consider briefly the internal scope. Suppose again that a portion of the citizenry 
is treated unjustly, and stands in need of compensation. Here we would not, on the subsidiary account, start by checking whether the citizens as such are able to compensate. The reason is first, that some of the citizens are victims, and second that all citizens, collectively, are considered as potentially liable only to the extent that this is useful, which will most likely not be true in cases where a portion of the citizenry is oppressed. Thus, in the domestic context, we simply ask whether the group of citizens who is not subject to discrimination, is able to compensate. Then we ask whether or not this group is the least able, and so on, all the while taking into account the incentive effect.

\section{Individual Moral Responsibility}

So far, I have considered the liability that citizens can incur without necessarily being morally responsible. As noted, however, some citizens may also in fact be morally responsible to some extent, perhaps because they endorsed, voted for, or rallied in favor of, the harmful act or policy. ${ }^{23}$ This raises the following question: Is it really fair to treat citizens symmetrically, even though some have endorsed, while others have opposed, the objectionable act or policy (Pasternak 2011, 190-1)? Intuitively there is a difference between, say, fierce anti-war demonstrators and hard-nosed warmongers. Even if all citizens are collectively liable (which may not always be the case, but which we assume here), a subset of the citizens may, in addition, be to some extent morally responsible for the harm. And surely, moral responsibility may, among other things, render agents liable to compensate victims.

The distinction between citizens who are collectively liable only, and citizens who are collectively liable and liable because they are to some extent morally responsible, is important, and should be explicitly addressed. ${ }^{24}$ This question also arises on the democratic authorization account. Parrish suggests briefly that citizens may be liable to different degrees, based on whether or not they endorsed or opposed the harmful act $(2009,149) .{ }^{25}$ 
Ideally, liability should primarily be distributed among morally responsible agents, including morally responsible citizens. Only subsequently should non-morally responsible citizens be held liable. Suppose that the citizens of a state have to compensate for the damages in the wake of an unjust war, and that the compensation eventually is paid by individual taxpayers. In such cases, it seems fair to hold citizens differentially liable, based on whether or not they endorsed or opposed the unjust war.

Pasternak cites two reasons against distributing liability in this way. First, it might cause tension and conflict between citizens, and secondly, it is obviously highly impractical (2011, 192). While both these concerns are valid, they do little, as Pasternak duly notes, to undermine the principle in general. Rather, the objections point to feasibility constraints that should be taken into account at the level of implementation. Thus, we should distinguish between morally and non-morally responsible citizens to the extent possible, and to the extent that doing so does not entail negative consequences that outweigh the gains.

Notice that this might also have implications for non-citizens. Suppose that two states are contemplating waging an unjust war, and only one of them goes through with it. In such cases, citizens who opposed the war (in the state that went to war), are liable, whereas those who endorsed the war (in the state that declined), may not be (Parrish 2009, 150). In this example the pro-war citizens in the state that ended up not going to war, are, it seems, morally responsible, at least for trying to make their state commit an unjust act. One might think that they are less responsible than those citizens who endorsed the war in the state that actually went through with it (depending on how we evaluate imposing harm versus attempting to impose harm), but they are morally responsible to some extent nevertheless. What then, should we think about the relationship between responsible non-citizens versus nonresponsible citizens? To be sure, it is quite hard to be precise about the relative level of liability among non-responsible agents who are liable in virtue of a combination of their 
ability and incentive considerations, and agents who are liable (because responsible) in virtue of having endorsed a (similar) harm that did not in the end materialize. In my view, however, the latter should be at least as liable as the former.

Again, however, feasibility considerations loom large. I will not argue that liability can in practice be distributed in light of these concerns, only that they ought to, and that we should be alert to any opportunity to distribute liability as close to the ideal as possible. It should be no objection, moreover, that this ideal will almost certainly not be fully attained. In general, most of us think that morally responsible agents should compensate their victims, but we seem willing, nonetheless to distribute the burden of compensation among able nonresponsible agents, when the responsible agent does not own up to his or her compensatory responsibilities.

\section{Concluding Remarks}

In closing, it bears repeating that the view I have proposed is compatible with the democratic authorization account. I have not criticized or dismissed that account as such. I have mainly pointed to some limitations of scope. It is possible to hold that democratic authorization renders citizens liable so long as the state acts inside its mandate, but when it goes outside of it, other grounds, for instance the subsidiary account presented here, are necessary to secure liability. Further, the democratic authorization account might integrate the goal of distinguishing between those who support and oppose unjust and harmful acts committed by the state. As I have already noted, Parrish indicates such a differentiation.

Regardless of whether the two accounts are compatible, however, it is worth underlining that my proposed subsidiary view has a (very) wide scope, and that it in that sense responds to one of the most important challenges to theories of collective liability, namely the importance of not leaving innocent victims to their own fate. 
Acknowledgments: For very useful comments on earlier versions of this paper, I am grateful to Kim Angell, Lars Christie, Jakob Elster, Eva Erman, Göran Duus-Otterström, Max Fonseca, Clare Heyward, Cathrine Holst, Fredrik Dybfest Hjorthen, Mats Lundström, Jouni Rainikainen, and two anonymous reviewers for this journal. Work on this article has been supported by the Norwegian Research Council (Grant number: 222541). 


\section{References:}

Butt, D., 2009. Rectifying International Injustice - Principles of Compensation and Restitution between Nations. Oxford: Oxford University Press.

Caney, S., 2010. "Climate Change and the Duties of the Advantaged." Critical Review of International Social and Political Philosophy 13 (1), 203-228.

Collins, Stephanie. 2016. “Distributing States' Duties.” Journal of Political Philosophy 24, 344-366.

Huseby, Robert 2015. "Should the Beneficiaries Pay?” Politics, Philosophy \& Economics $14,209-225$

Miller, D., 2007. National Responsibility and Global Justice. Oxford: Oxford University Press.

Miller, D., 2001. "Distributing Responsibilities.” The Journal of Political Philosophy 9 (4), 453-471.

Nagel, T., 2005. “The Problem of Global Justice.” Philosophy and Public Affairs 33 (2), 113-147.

Pasternak, A., 2013. "Limiting State's Corporate Responsibility.” The Journal of Political Philosophy 21(4), 361-381.

Pasternak, A., 2011. "Sharing the Costs of Political Injustice.” Politics, Philosophy \& Economics 10 (2), 188-210.

Parrish, J., 2009. “Collective Responsibility and the State.” International Theory 1 (1), 119154.

Pettit, P., 2007. “Responsibility Incorporated.” Ethics 117 (2), 171-201.

Pogge, T., 2002. World Poverty and Human Rights. Cambridge: Polity Press.

Rawls, J., 1999. The Law of Peoples. Cambridge MA: Harvard University Press.

Stilz, A., 2011. "Collective Responsibility and the State.” The Journal of Political Philosophy 
19(2), 190-208. 
${ }^{1}$ Of course, states are rarely held responsible in a morally adequate way, but that does not say anything about whether they should. Further, other forms of reparation can also be warranted, but here I focus only on compensation.

${ }^{2}$ I will, however, discuss morally responsible citizens in the penultimate section.

${ }^{3}$ Some authors use other terms, such as consequential responsibility (Pasternak 2011), task-responsibility (Stilz 2011), and assignment responsibility (Parrish 2009). These terms all refer to a duty to fix some bad state of affairs that does not rely on blame or moral or causal responsibility. While I prefer the term liability, nothing substantial hangs on the terminology here.

${ }^{4}$ The account can also be extended to non-democracies (Parrish 2009; Nagel 2005). Here, I will only discuss it in relation to democracies.

${ }^{5}$ There are, of course, alternative ways of grounding liability. For instance, we might think that if someone for some reason benefit from (wrongful) harm to others, they should, for that reason, foot the bill (Butt 2009; Collins 2016; Huseby 2015). Another ground for liability are so called associative duties arising from some special relationship between the victim and the potential compensator (Miller 2001). I will not assess these possibilities here.

${ }^{6}$ Pettit $(2007,194-7)$ raises similar concerns, as does Collins (2016, 345-346).

${ }^{7}$ I remain agnostic, however, as to whether the democratic authorization view is, in the end, justifiable. My subsidiary account can if necessary serve as a stand-alone version of liability.

${ }^{8}$ I do not consider Nagel here, since he only hints at the implications his theory might have for collective liability.

${ }^{9}$ Stilz here draws explicitly on Kant.

${ }^{10}$ It is unclear here whether this is a specifically moral reason rather than a prudential one.

${ }^{11}$ A principal-agent relationship is a relationship in which the principal authorizes an agent to act on her behalf. Such relationships are commonplace. Citizens in democracies are principals with regards to elected politicians, who are agents. The government is principal with regards to bureaucrats, who are agents, and so on.

${ }^{12}$ By 'responsibility' Parrish means 'assignment responsibility,' which is similar to liability.

${ }^{13}$ Stilz argues that the war was aggressive and probably illegal, but she does not use the term unjust.

${ }^{14}$ The mandate should also encompass some reasonableness considerations. If a state commits unjust or illegal acts in spotless good faith, the citizens might still be held liable. 
${ }^{15}$ There could be gray areas here. Some states may be nearly legitimate, and so on. Further, there can be reasons to obey the law that does not stem from the legitimacy of the regime (for instance reasons of stability).

${ }^{16}$ In my view, the democratic authorization account will most likely accept alternative b). While this alternative may indeed be morally problematic, it seems at least consistent with the theory as such. Accepting alternative a) on the other hand, will imply that the account rests on different, and incompatible, accounts of legitimacy.

${ }^{17}$ See also Miller (2001, 460-461).

${ }^{18}$ This might point to another, and different, limitation of the scope of the democratic authorization account. If the liable citizens are unable to compensate, the cost of the harm will remain with the victims.

${ }^{19}$ One might worry that this reasoning may generalize in such a way that one ends up being liable for all sorts of things that one is (minimally) able to influence. I do not think this concern is warranted. In the cases under discussion, some victims experience severe deprivation, and there is a lack of agents with clear duties to compensate. In cases like this, we should consider liability of the kind I propose, but even then, we should accept it only after close evaluation of the overall implications and consequences.

${ }^{20}$ While I restrict my attention to democracies, it seems plausible that the account also covers cases of nondemocracies in which citizens still have some influence over state policy.

${ }^{21}$ Or subgroup. See below.

${ }^{22}$ Another question concerns the extent to which the duties that follow from my proposed account of collective liability are such that they can legitimately be coercively enforced. I am not completely sure, but it seems to me at least that this account can form the basis of an international compensation scheme that can in turn inform and be codified by law. At this stage, if not sooner, the duties will be coercively enforceable.

${ }^{23}$ Notice that it is far from straightforward to establish that an individual is (to some extent) morally responsible for state harm in virtue of having endorsed or voted in favor of the harm. For one thing, the causal influence voters have on electoral outcomes is microscopic. My view is that it is morally wrong to support and vote in favor of, say, racist policies or aggressive and illegal wars, and that doing so may render individual citizens to some extent morally responsible. However, it is not my aim here to examine this question in detail. It sufficient for my purposes that individual citizens may sometimes be morally responsible for some state inflicted harm, and that this may render them (among other things) liable. Here, I assume that endorsing or voting for wrongful state acts may ground moral responsibility. 
${ }^{24}$ Being morally responsible may also render agents liable to blame. In the present context, however, liability to pay compensation to victims is my main concern.

${ }^{25}$ Stilz does not, as far as I can see, address this question. There is no reason, however, to doubt that the democratic authorization account is able to distinguish between morally responsible and non-morally responsible citizens. 